\title{
MEDICO-LEGAL RESPONSIBILITY IN MANAGEMENT OF ACUTE AND CHRONIC PAIN IN OBSTETRIC
}

\author{
Dubravko Habek ${ }^{1,3}$ Ivan Šklebar ${ }^{2,3}$ \\ ${ }^{1}$ Clinical Departement of Obstetrics and GynecologyClinical Hospital „Sveti Duh“ Zagreb, Croatia; \\ ${ }^{2}$ Anestesiology, Reanimaology and Intensive Medicine** Clinical Hospital „Sveti Duh“ Zagreb, Croatia; \\ ${ }^{3}$ Croatian Catholic University Zagreb, Croatia
}

\begin{abstract}
SUMMARY - Medico-legal responsibility in the management of acute or chronic pain in broad sense implies acting by the rules of good clinical practice and reducing the potential treatment side effects and complications that may entail health impairment and possible legal proceedings. Patients with acute or chronic obstetric or nonobstetric pain should be informed on the mode and method of treatment, possible side effects, and effects of drugs or procedures on fetal growth and development (informed consent). The principles of perinatal pharmacology and toxicology should be respected, choosing the mode of treatment associated with the lowest rate of side effects and a minimally invasive procedure (Accordingly, medico-legal responsibility is a professional and deontological category that should be fostered and implemented in line with professional guidelines and safety for both patients and medical staff.)
\end{abstract}

Key words: forensic, legal medicine, acute pain, chronic pain, obstetric

\section{Introduction}

Medico-legal responsibility in the management of acute or chronic pain in broad sense implies acting by the rules of good clinical practice and reducing the potential treatment side effects and complications that may entail health impairment and possible legal proceedings. The potential risks and legal issues can be reduced by proper information and education of physicians, midwives, physiotherapists and nurses involved in the management of pain in obstetrics, with individualized approach of the current personalized medicine. Patients with acute or chronic obstetric or nonobstetric pain should be informed on the mode and method of treatment, possible side effects, and effects of drugs or procedures on fetal growth and develop-

Correspodence to: Prof. Dubravko Habek, $M D, M S C, P h D, P h D$, Clinical Departement of Obstetrics and Gynecology Clinical Hospital „Sveti Duh“ Zagreb and Croatian Catholic University Zagreb, Ilica 242, Zagreb, Croatia

e-mail: dhabek@unicath.hr ment (informed consent). The principles of perinatal pharmacology and toxicology should be respected, choosing the mode of treatment associated with the lowest rate of side effects and a minimally invasive procedure (1-3).

\section{Acute and Chronic Pain in Obstetrics}

Although thorough neuroscientific research is not applicable to the maternal-fetal unit, in the past twenty years, ultrasound studies and functional magnetic resonance imaging (fMRI) have pointed to objective events in the brain during pain as specific biomarkers, even in pregnancy in both maternal and fetal brain, fully respecting neuro-ethics components in order to obviate subjective experiences (4).

Treatment of acute and chronic pain in obstetrics includes medicamentous, acupuncture, surgical and neural blockade therapy. Types of acute and chronic pain in obstetrics are shown in Table 1 . Acute pain in obstetrics generally refers to acute abdomen and vis- 
Table 1. Possible causes of acute and chronic pain in obstetrics

\begin{tabular}{|l|l|}
\hline Acute pain & Chronic pain \\
\hline Acute abdomen & Chronic lumboishialgia \\
Acute pelvic pain & Chronic pelvic pain \\
Urocolic & Chronic headache \\
Biliary colic & Chronic dorsal pain syndroma \\
Acute lumboishialgia & \\
Acute headache & \\
\hline
\end{tabular}

ceral pain, and pain relief in peripartum $(1,2,5)$. In hospitals, acute pain services are mostly led by anesthesiologists interested in algology, and their services are specifically used in obstetric anesthesia due to specific features of antepartum, peripartum and postpartum periods, be the pregnancy terminated by spontaneous or surgically assisted delivery. Nowadays, regional anesthesia with epidural analgesia during delivery is very popular, as well as inhaled nitric oxide, ordering intravenous opioid petantin or remifentanil, acupuncture analgosedation, and ordering homeopathic preparations. In western countries where midwives lead normal deliveries, i.e. the majority of deliveries (up to $70 \%-80 \%$ ), the most common types of peripartum acute analgesia are inhaled nitric oxide and intravenous opioid ordering, acupuncture and homeopathy. These methods have been used for decades with excellent compliance, safe for both mother and child (1-7).

Chronic pain is defined as daily pain suffered $>50 \%$ of days over three months. In obstetrics, it can be musculoskeletal, vascular or visceral, and may require chronic medication or physical therapy/acupuncture. These conditions are quite rare because biohumoral changes in pregnancy, in particular the effect of progesterone as a psychoneurotropic agent alleviates painful conditions. The environmental emotional experience of (acute) peripartum pain as a complex sensoriemotional experience related to tissue damage certainly is also pronounced, as compared with the definition of nociception that includes neuronal process of encoding noxious stimuli $(1,4)$. Chronic pain will frequently manifest as psychosomatic or neuropathic/reflex pain (e.g., chronic pelvic pain syndrome).

Obstetric patients at a high risk are adipose women, those with preeclampsia, diabetes, immobile due to neurologic disorders, those with thrombophilia on heparin therapy, those with treated sepsis or thromboembolic disease in pregnancy, and pregnant women and puerpera having undergone extensive operative procedures (treatment of postpartum hemorrhage, obstetric hysterectomy) $(1,2,5,7)$.

The following should be ensured for safe procedures in obstetric algology: educated anesthesiologists, obstetricians and midwives; algological problem identified; individualized evaluation of the methods of treatment for each pregnant woman/puerpera; and patient identification, thorough history with clear data on possible medications and allergic reactions $(5,8,9)$.

\section{Discussion}

The management of painful conditions and pain relief are routine procedures in obstetrics, which should be generally available. In the past decade, emphasis has been put on patient autonomy in the choice of therapy, also implying obstetric analgesia/anesthesia. However, it is physician's responsibility to present the need of an operative or diagnostic procedure including the mode and type of analgesia/anesthesia, i.e. treatment of acute or chronic pain, to lay persons.

Patient safety is, among other issues, based on proper presenting the mode of acute or chronic pain management, therapeutic options in line with the methods accepted by the profession, and logistics offered by inpatient or outpatient healthcare $(1,2,5,10)$.

Nowadays, analgesia is available to everybody, and modern obstetrics and midwifery are hard to imagine without some type of conventional or complementary analgesia. Therefore, the clause on pain suffering during delivery and postoperatively, along with pain categorization into severe, moderate and mild pain is forensically questionable because pain is qualified according to the analgesics prescribed.

Operative technique of the $21^{\text {st }}$ century that is classified as a minimally invasive procedure with appropriate analgesia available, pain categorization and consequential charges for pain suffering should be perceived from this aspect. However, current indemnity charges continuingly demand forensic expertise for having suffering postoperative pain. Therefore, medical forensic experts should take into account the clause on therapy ordered in immediate postoperative period and pain treatment delivered $(1,2,5,10,11)$. 
Data show an increase in the number of indemnity charges for postoperative pain from 6\% (1980) to 8\% (2000) and for chronic pain from 7\% (1985-1994) to $12 \%(1995-2004)(12,13)$. Errors were most commonly recorded in prescribing drugs and incorrect drug doses (44\%), followed by erroneous drug administration (30\%) and erroneous medication timing (8\%) (14). Forensic expertise should assess whether chronic pain has developed as a sequel of acute pain or a condition preceding chronic pain occurrence, or due to a chronic condition, e.g., although very rare, post-puncture headache and consequential chronic headache are described elsewhere.

In elective and emergency obstetrics and anesthesia, the idea of patient preference and procedure on request may be associated with serious consequences including transient or permanent disability and anaphylaxis, thus it should be avoided based on good practice and deontological principles. Although the term of defensive medicine is known in obstetrics, there is no evidence for doing well by increasing the rate of nonmedical cesarean sections in this context. On the contrary, indicated elective cesarean sections and repeat cesarean sections are associated with higher rates of maternal morbidity and mortality, and of short- and long-term, lifelong morbidity of children born by elective cesarean section. Obstetrics and obstetric anesthesia are not aesthetic fields of medicine, thus performing operative procedure as a legally defined disruption of body integrity (injuries) and regional anesthesia as invasive and aggressive procedures is inconceivable irrespective of liberalized patient autonomy. In this case, patient autonomy is not a category of patient safety $(1,2,7,10)$. Therefore, uncritical and independent approach to treatment and using methods lacking scientific grounds is not allowed. A mode of treatment that is beyond the frames of good clinical practice and deontological approach (primum non nocere) should not be presented to patients, irrespective of the potential harm or benefit. Accordingly, medico-legal responsibility is a professional and deontological category that should be fostered and implemented in line with professional guidelines and safety for both patients and medical staff.

\section{References}

1. Habek D, Šklebar I, Jurković I, Šakić K, Hrgović Z. Forensic in obstetrics anesthesia. Period Biol. 2013;115:149-52

2. Šklebar I, Habek D, Jurković I. The correlation between patient safety culture and regional anesthesia development. Period Biol. 2013;115:239-46

3. Racz G, Nie C, Munglani R. Medico - legal Aspects of Pain Medicine. IntechOpen. 2014; 3-20. doi.org/10.5772/58754

4. Davis KD, Flor H, Greela HT, Ianetti GD, Mackey S, Planer M, Pustiinik A, Tracey I, Treede RD, Wager TD. Brain imaging tests for chronic pain: medical, legal and ethical issues and recommendations. Nature Reviews in Neurology. 2017;1-15

5. Scholfield R. Risk management in obstetrics. Curr Obstet Gynaecol.2005;15:237-83

6. Habek D, Čerkez Habek J, Pišl Z, Vuković-Bobić M. Acupuncture analgosedation in the ambulance gynaecologic operative procedures. Gebursthilfe Frauenheilkd. 2005;65:678-81

7. Clements RV. Risk Management and Litigation in Obstetrics and Gynaecology. RCOG and RSM Press, London,2004; p 30-170.

8. Sohn DH. Negligence, genuine error, and litigation. Int J Gen Med. 2013;6:49-56

9. Posner KL, Caplan RA, Cheney FW. Variation in expert opinion in medical malprac- tice review. Anesthesiology. 1996; 85(5):1049-54

10. Evans PJD. Medico - legal aspects of pain. Curr Anest Crit Care. 1998;9:290-5

11. Kalauokalani D. Malpractice Claims for Nonoperative Pain Managment: A Growing Pain for Anesthesiologists? ASA Newsletter. 1999;63(6):16-8

12. Liau D. Trends in Chronic Pain Management Malpractice Claims. ASA Newsletter. 2007;71(8).

13. Fitzgibbon DR, Posner KL, Domino KB, Caplan RA, Lee LA, Cheney FW, et al. Chronic pain management: American Society of Anesthesiologists Closed Claims Project. Anesthesiology. 2004;100(1):98-105.

14. Sandnes D, Stephens L, Posner K, KB D. Liability Associated with Medication Errors in Anesthesia: Closed Claims Analysis. Anesthesiology. 2008;109(A770) 


\section{Sažetak \\ MEDIKO - LEGALNA ODGOVORNOST \\ U MANAGEMENTU AKUTNE I KRONIČNE BOLI U OBSTETRICIJI}

D. Habek i I. Šklebar

Bolesnica sa akutnom ili kroničnom opstetričkom ili neopstetričkom boli mora biti informirana o načinu i vrsti liječenja, mogućim nuspojavama i učincima lijekova ili postupaka na fetalni rast i razvoj (informirani pristanak). Moraju se poštivati postulati perinatalne farmakologije i toksikologije i izabrati način liječenja koji će imati najmanje nuspojava i biti minimalno invazivni zahvat. Stoga je mediko legalna odgovornost profesionalna i deontološka kategorija koju valja gajiti i primjenjivati u skladu sa stručnim smjernicama i profesionalnom sigurnošću za pacijente i medicinsko osoblje.

Ključne riječi: forenzika, akutna bol, kronična bol, porodništvo 